\title{
Arquitectura y Símbolo. Iconografía de la Catedral de Málaga
}

Discurso leído por la Illma. Rosario Camacho Martínez el día 24 de septiembre de 1987 en su recepción académica y contestación del Illmo. Sr. D. César Olano Gurrián. Málaga, Real Academia de Bellas Artes de San Telmo, 1988

Marina Castilla Ortega

Universidad de Málaga

Voy a centrarme en este discurso de la Dra. Camacho, probablemente uno de los más emblemáticos de toda su trayectoria. Fue leído el día 24 de septiembre de 1987 durante su recepción académica en la Real Academia de Bellas Artes de San Telmo de Málaga con el deseo expreso de homenajear al padre Andrés Llordén ${ }^{1}$, a quien sucedió tras su fallecimiento en dicha institución, enlazándolo, de este modo, con sus estudios sobre la Catedral ${ }^{2}$. Al mismo tiempo, quiso conmemorar una fecha tan importante para la ciudad, como fue el Quinto Centenario de su adhesión a la Corona de Castilla, en $1487^{3}$.

Con su discurso, la Dra. Camacho desarrolló una lectura de la Catedral mediante la conexión entre forma, imagen y símbolo. Además, con el rigor científico y la claridad expositiva que la caracterizan, realizó un minucioso y amplio recorrido de la misma, tanto histórico como arquitectónico, desde el siglo XV al XIX, haciendo recuento de los interventores más importantes en su configuración ${ }^{4}$, junto con otras curiosidades, como el proyecto de planta utópica en forma de concha de tortuga del Canónigo Bolea y Sintas (siglo XIX). Así mismo, para esta investigación pretendió esclarecer cuestiones sobre sus orígenes, edificación y autoría, por lo que su estudio podría calificarse de inédito, para lo cual se apoyó en un importante y variado legado documental ${ }^{5}$.

1 Llordén no solo llegó a ser su referente y guía académico, sino que también, y sobre todo, forjaron una gran amistad.

2 La línea de investigación del padre Llordén se centró en la Historia del Arte de Málaga, constituyendo un auténtico hito para la Dra. Rosario Camacho Arquitectos y canteros malagueños, 1962, puesto que, como bien admite, dicha obra fue... compañero indispensable de mis primeras investigaciones, p. 11. 3 Finalmente, recibió las honoríficas palabras del académico D. César Olano, junto con los elogios y felicitaciones el Colegio de Arquitectos de Málaga y las cartas de los profesores D. José Pita Andrade, D. Antonio Bonet Correa, D. Domingo Sánchez-Mesa Martín y D. Juan Antonio Ramírez, pp. 63-70.

4 Algunos de ellos fueron el cardenal Riario y el deán Fernando Ortega y los artífices Diego de Siloe, Pedro López, Diego de Vergara, Andrés Vandelvira, Hernán Ruiz I y III y José de Bada.

5 Las fuentes esenciales para este estudio, se constituyen por libros de emblemas morales, como los de Cesare Ripa (1603) y Juan de Borja (1697), el tratado de arquitectura de Serlio (1537), testimonios y crónicas de época, estudios de otros investigadores contemporáneos dedicados a la Catedral (Medina Conde, M. ${ }^{a}$ Dolores Aguilar), las Sagradas Escrituras y otros textos de literatura no religiosa. 
En primer lugar comenzó con un práctico resumen sobre la tradición simbólica o parlante de la arquitectura litúrgica a lo largo de la historia, partiendo de culturas ancestrales como la egipcia, pasando por los mausoleos romanos y los martirias medievales. $A$ este grupo de construcciones se adscribe claramente esta Catedral, como mensajera de ideas propagandísticas del Cristianismo. Por una parte, para llevar a cabo sus objetivos, este tipo de edificaciones suele apoyarse en elementos puramente formales (la forma como vehículo de una idea), como la geometría de sus plantas. En el caso concreto de la Catedral, se conforma una fusión entre el plan longitudinal o axial, con referencias a las basílicas romanas y a la cultura judía (la vida como camino) y el centralizado elíptico (la Catedral como centrum), de clara inspiración borrominiana.

Por otro lado, también serán fundamentales los elementos decorativos con sus consiguientes programas iconográficos. Partiendo del contexto de la Reconquista, de la que destacó su carácter de cruzada o cristianizador, por el que se adoptó la Virginidad de María como estandarte del Catolicismo, la Catedral constituye una auténtica oda a la Inmaculada Concepción y la Redención a través de la Fe. Ambas temáticas, se manifiestan a partir de un vasto despliegue iconográfico concentrado, mayoritariamente, en la
Capilla Mayor, las portadas y las bóvedas, primando aquellos elementos explicativos del Misterio de la Encarnación, como el jarrón de azucenas, y los atributos iconográficos de la Virgen Apocalíptica, como el espejo, la estrella y la torre, entre otros. A ello se une la profusión de otros símbolos cristológicos, de la sabiduría divina (obeliscos y pirámides) y los ciclos de la Pasión. Todo ello, queda reforzado a través de personajes míticos prefiguradores de Cristo y de la Virginidad de María, provenientes del Antiguo Testamento (la Vieja Iglesia o Sinagoga); Ios Santos Mártires, como emblemas de la Iglesia Triunfante; los doce Apóstoles y los cuatro Evangelistas; las Virtudes Cardinales y Teologales y los Padres de la Iglesia, base de interpretación cristiana, aparte de otros simbolismos, como la idea de fortaleza en el exterior (la Turris Davídica de la Letanía Lauretana, según Juan Antonio Ramírez), y las referencias al prototípico Templo de Salomón, tanto en la longitudinalidad de la planta como en la presencia de las columnas Xaquim y Boaz en el tímpano.

En definitiva, con este discurso, la Dra. Rosario Camacho lleva al lector a conocer y a apreciar mejor la Catedral de Málaga, no solo desde el punto de vista de su grandeza histórica y material, sino también simbólica, quizás una faceta menos difundida de la misma. 